\title{
METHODICAL APPROACHES TO MANAGING THE EFFICIENCY OF ENTERPRISE RESOURCES
}

\author{
Petro Mykytyuk ${ }^{1}$ \\ pp.mykytiuk@gmail.com \\ Iryna Trush \\ iratrush22@gmail.com \\ ${ }^{1}$ Department of Management, Public Administration and Personnel \\ West Ukrainian National University, \\ 11 Lvivska str., Ternopil, Ukraine, 46009
}

\section{Abstract}

Methodical approaches to the analysis of the efficiency of material recourses use in building organizations on the basis of economic-mathematical models are offered. The phenomena, related to supply and storage of materials, their production use and impact of material supply on the financial structure of capital, occurred in the enterprise, are determined by means of the analysis of the production functions of dependence of return of fixed assets on material resources, and it was also investigated how such phenomena affect the return on fixed assets. On this basis, the recommendations how to improve the management of materials supply in order to provide the fullest use of fixed assets are developed. Based on the study of the value of the coefficients of linear models of dependence of the financial indicators of the enterprise activity on the value of material stock, the price of a unit of stock, the types of stock, on which the profitability of the enterprise significantly depends are determined, and it is also defined what economic, financial, organizational and technological regularities are covered by these dependencies. An economic interpretation of such dependencies is given and the recommendations for improving stock management and the material supply structure are developed. The qualitative analysis of dependence of the financial indicators of the enterprise activity on the value of the stock and its cost is carried out. The recommendations for improving the management of the size and the price structure of the most important material stock are developed.

Keywords: organizations, fixed assets, efficiency of fixed assets, efficiency of material resources, linear models.

DOI: $10.21303 / 2504-5571.2021 .001605$

\section{Introduction}

The concept of resource efficiency implies the need to improve the system of resource provision for the activities of organizations in order to increase resource use efficiency, as well as carrying out comprehensive analysis, which includes providing, identifying and mobilizing existing and potential reserves [1]. The main objective of carrying out the analysis of the efficiency of contracting construction organizations productive resources use is the timeliness of studying of changes in economic processes that either threaten to withdraw the organization from a given direction or rate of development, or indicate the emergence of additional reserves, which will enable its quick conversion into an effective mode of operation [2]. The value of the carried out analysis of production resources depends on the timely use of the analytical information and the way it affects the processes of production and sales of building products [3].

It is also needed to compare the impact of material supply and the impact of providing with basic resources on the financial indicators of the enterprise operation [4]. In particular, to find out how changes of the value of supply and the value of fixed assets affect the profitability of the enterprise, what economic phenomena occur at the optimal level of these values and when deviating from them [5]. To find out how the profitability of fixed assets changes with deviations of the stock value from the optimal value. To make recommendations how to improve the joint management of fixed assets and material stocks use that are among the determinants of raising the efficiency of construction [6]. 
Fixed assets are the material and technical base of production, the foundation for its improvement and development. This process takes place by both increasing the potential of fixed assets (extensively) and increasing the efficiency of their use (intensively) [7]. A significant increase in fixed assets leads to complications in the technical re-equipment of production, moral and physical aging of equipment, which reduces the efficiency of its use and the possibility of conversion [8]. Therefore, it is more economically justifiable to increase the time of operation of the equipment, to load the available park to the full extent, to maintain its operation in the most qualified way, etc [9].

The issues of analysis of the provision of organizations material resources constitute the basis for formation and development of the conceptual principles for the analysis of use of enterprises resources [10]. However, changes in market conditions, instability and a number of other characteristics of the national economy in general and of building construction organizations in particular, actualize the need for theoretical substantiation and development of methodological approaches to the managing of the efficiency of building organizations material resources use, adaptable to present continuous, focused on modeling their development strategy taking into account changes in external and internal environment of their operating [11].

\section{Materials and Methods}

For the analysis of supply of the construction organization with material resources, an experiment was carried out to calculate the dependence of the return on fixed assets on the structure of material supply.

The value of the return on the unit of fixed assets is known.

$w(t)=y_{2}(t) / m_{7}(t)$

Therefore, using it, this is easy to calculate model coefficients which will indicate the impact of individual types of materials on the overall profitability of the fixed assets.

A polynomial model was developed for the value of the return on fixed assets (1)

$w=P\left(m_{1}, m_{2}, m_{6}\right)$.

Based on the reporting data of the CE "Special construction equipment" dependence on the time of cost is established

$$
v_{i}(t), i=1, \ldots, 14
$$

and prices

$$
c_{i}(t), i=1, \ldots, 14
$$

of basic building materials.

The above-given analysis of the impact of the structure of material resources of CE "Special construction equipment" is summarized in the methods, presented below.

Algorithm. Analysis of the influence of the structure of material resources on the performance of a construction company.

1. Based on the enterprise reporting data, to determine the dependence of productivity indin cators on time $y_{i}(t), i=1, \ldots, n_{y}$, where $n_{y}$ is the number of these indicators.

2 . Based on the enterprise reporting data, to determine the dependence of the material resources on time $m_{i}(t), i=1, \ldots, n_{m}$, where де $n_{y}$ is the number of these resources.

3. Based on the enterprise reporting data, to determine the dependence of the cost $v_{i}(t)$, and the price $c_{i}(t)$, of the material resources on time; $i=1, \ldots, n_{v}$, where $n_{v}$ is the amount of material resources.

4. Based on the enterprise reporting data, to determine the dependence of the balance of fixed assets $o_{z i}(t)$, income of fixed assets, $o_{p i}(t)$, their expenditure $o_{r i}(t)$, and the replacement of the fixed assets $o_{d i}(t) ; \mathrm{i}=1, \ldots, n_{o}, n_{o}$, where $n_{o}$ is the number of these indicators. 
5. To draw the graphs of the dependence of the profitability indicators on time $y_{i}(t), i=1, \ldots, n_{y}$.

6. To drown the graphs of the dependence of the material resources on time $m_{i}(t), i=1, \ldots, n_{m}$.

7. Comparing the graphs of $y_{i}(t)$ i $m_{i}(t)$, to carry out a qualitative analysis of these values, to establish economic regularities, which connect the profitability of the enterprise with its supply with material resources. In particular, to draw conclusions about the quality of work of services of material supply, their relation to technological needs, about the influence of material supply on financial indicators and the structure of the enterprise capital.

8. To build a linear model of the dependence of the financial indicators of the enterprise activity yi on the material stock mi:

$$
y_{i}=\sum_{k=1}^{n_{m}} \alpha_{k} m_{k}, i=1, \ldots, n_{y}
$$

where $\alpha_{i}$ are the coefficients of the linear model.

9. Analyzing the value of the parameters of the model yi, to determine which components of material resources have a significant direct and reverse effect on the profitability, and which have little effect on it. To give an economic interpretation for the established means.

10. In order to analyze the impact of material resources to build models of linear dependence of the profitability indicators yi on the residual value of fixed assets $o_{z i}$, income of fixed assets opi, their expenditure ori and replacement of fixed assets $o_{d i}$ :

$$
y_{i}=\sum_{k=1}^{n_{o}} \alpha_{k} o_{j k}, j=z, p, v, d ; i=1, \ldots, n_{y}
$$

where $\alpha_{i}$ are the coefficients of the linear models.

11. To calculate the values of the return on fixed assets $w_{i}(t), \mathrm{i}=1, . ., n_{w}$.

12. To draw the graphs of the dependence of the return on fixed assets on time $w_{i}(t), \mathrm{i}=1, . ., n_{w}$.

13. Comparing the graphs of productivity indicators $y_{i}(t)$, the structure of fixed assets $o_{j i}(t)$, the material resources $m_{i}(t)$, and the return on fixed assets $w_{i}(t)$, to specify conclusions about the dynamic impact of the structure of fixed assets and material supply on the financial indicators of the enterprise activity.

14. To draw a linear model of the dependence of return on fixed assets wi on the structure of material supply $m_{i}$ :

$$
w_{i}=\sum_{k=1}^{n_{m}} \alpha_{k} m_{k}, i=1, \ldots, n_{w},
$$

where $\alpha_{i}$ are the coefficients of the linear models.

15. Analyzing the values of the coefficients, to determine which types of material resources have significant, direct and diverse effects on the productivity of use of fixed assets and which have little effect on their productivity.

16. To draw graphs of dependence of the value $v_{i}(t)$ vi $(\mathrm{t})$ and price $c_{i}(t), \mathrm{i}=1, \ldots, n_{m}$ of materials, stored in the warehouses of the enterprise, ready for production use. services.

17. Comparing the graphs of $v_{i}(t)$ and $c_{i}(t)$, to define the conclusions on the quality of supply

18. Comparing the graphs $v_{i}(t)$ and $c_{i}(t)$ and the graphs $y_{i}(t), w_{i}(t)$, vi (t), to make up conclusions about the affect of a stock of material resource, its purchase price, the moment of purchase and the value of the lot on the financial indicators of the enterprise activity and on the efficiency of use of fixed assets. Based on these findings, to formulate recommendations for improving the enterprise work on supply of material stock.

19. To draw linear models of dependence of productivity indicators $y_{i}$ on cost $v_{i}$ and material stock price $c_{i}$ : 


$$
\begin{aligned}
& y_{i}=\sum_{k=1}^{n_{m}} \alpha_{k} v_{k} \\
& y_{i}=\sum_{k=1}^{n_{m}} \alpha_{k} c_{k} \\
& y_{i}=\sum_{k=1}^{n_{m}} \alpha_{k} v_{k}+\sum_{k=1}^{n_{m}} \alpha_{k} c_{k},
\end{aligned}
$$

where $i=1, \ldots, n_{m}, \alpha_{i}$ are the coefficients of the linear models.

The schematically described method of analyzing the impact of material supply structure on the financial indicators of the enterprise activity is shown in Fig. 1.

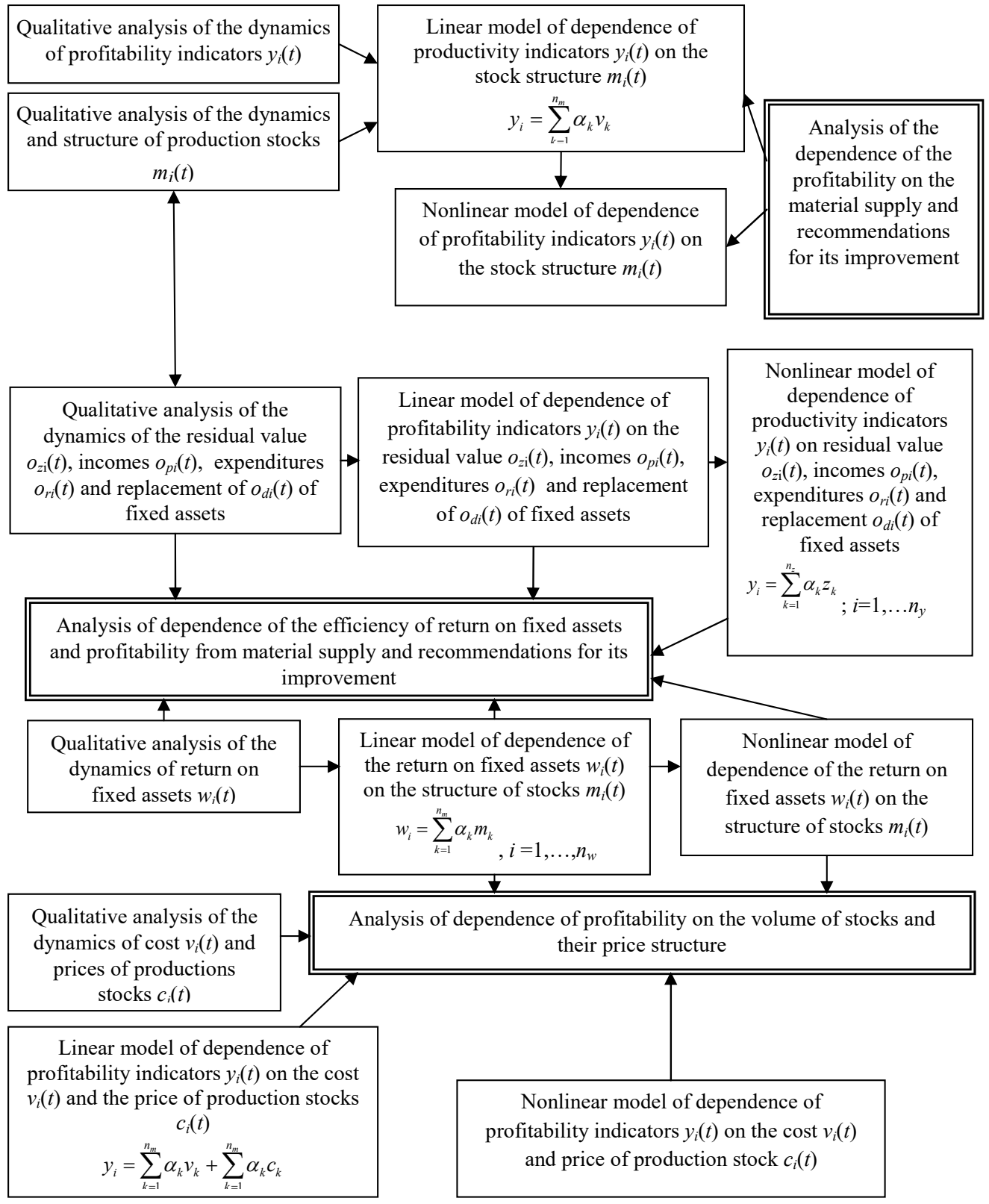

Fig. 1. Scheme of modeling and analysis of the impact of material resources on the resulting indicators of the activity of contract construction organizations 
Algorithm and Fig. 1 reflect the methods of analysis, developed during the research of the JSC PJSC "Lvivmiskbud” and CE "Special construction equipment".

\section{Results}

As a result of calculating experiments, it is found out, that when the prices of individual materials are brought to a common relative scale (by means of rationing per unit), the return on fixed assets (Fig. 2) starts to depend only on the stock of raw and other materials. The diagram of values of coefficients of the linear multifactoral model for the real values is shown in Fig. 3. This chart only shows which components of material supply positively, and which of them have a negative impact on the return on fix assets, but it does not present conclusions about the extent of this impact.

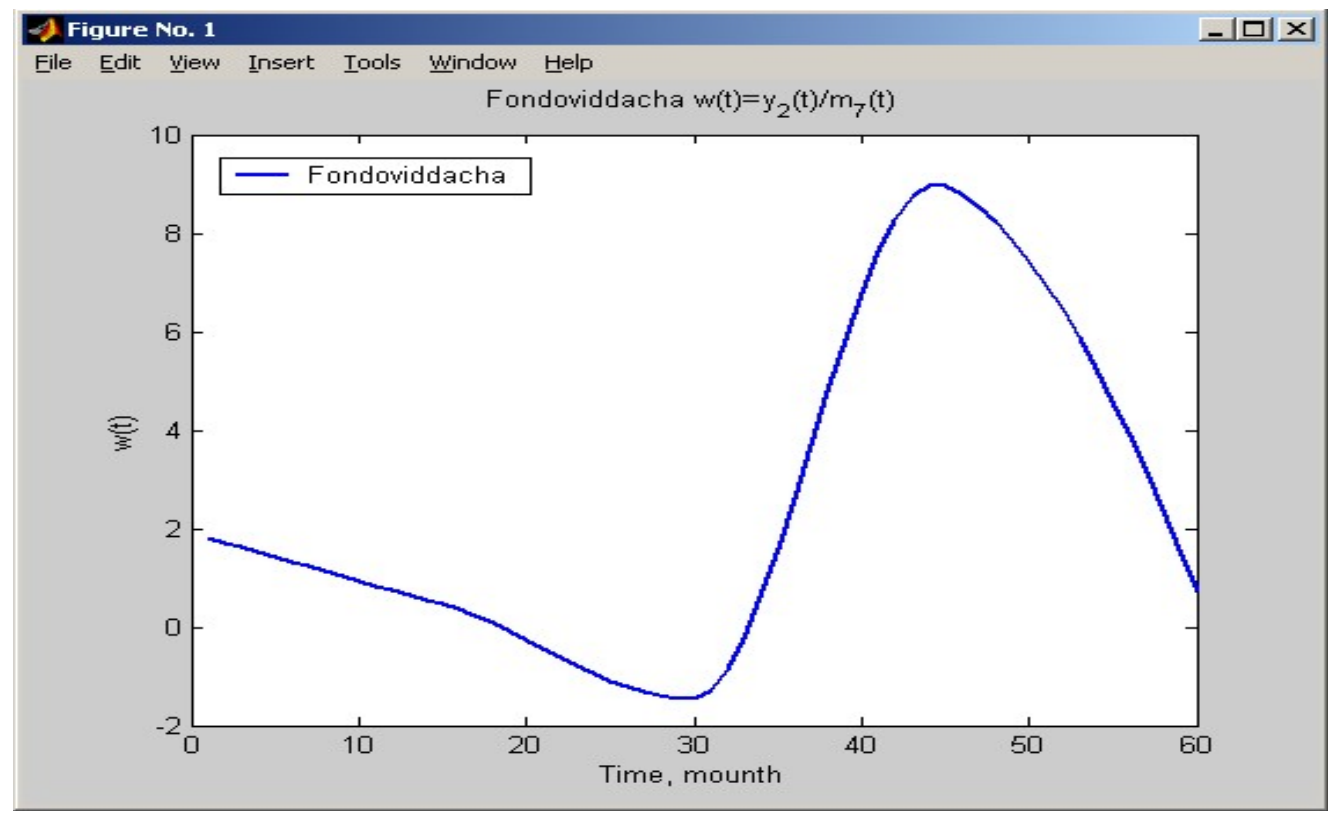

Fig. 2. Graph of gross net income from sale of products per unit of value of fixed assets of CE "Special construction equipment"

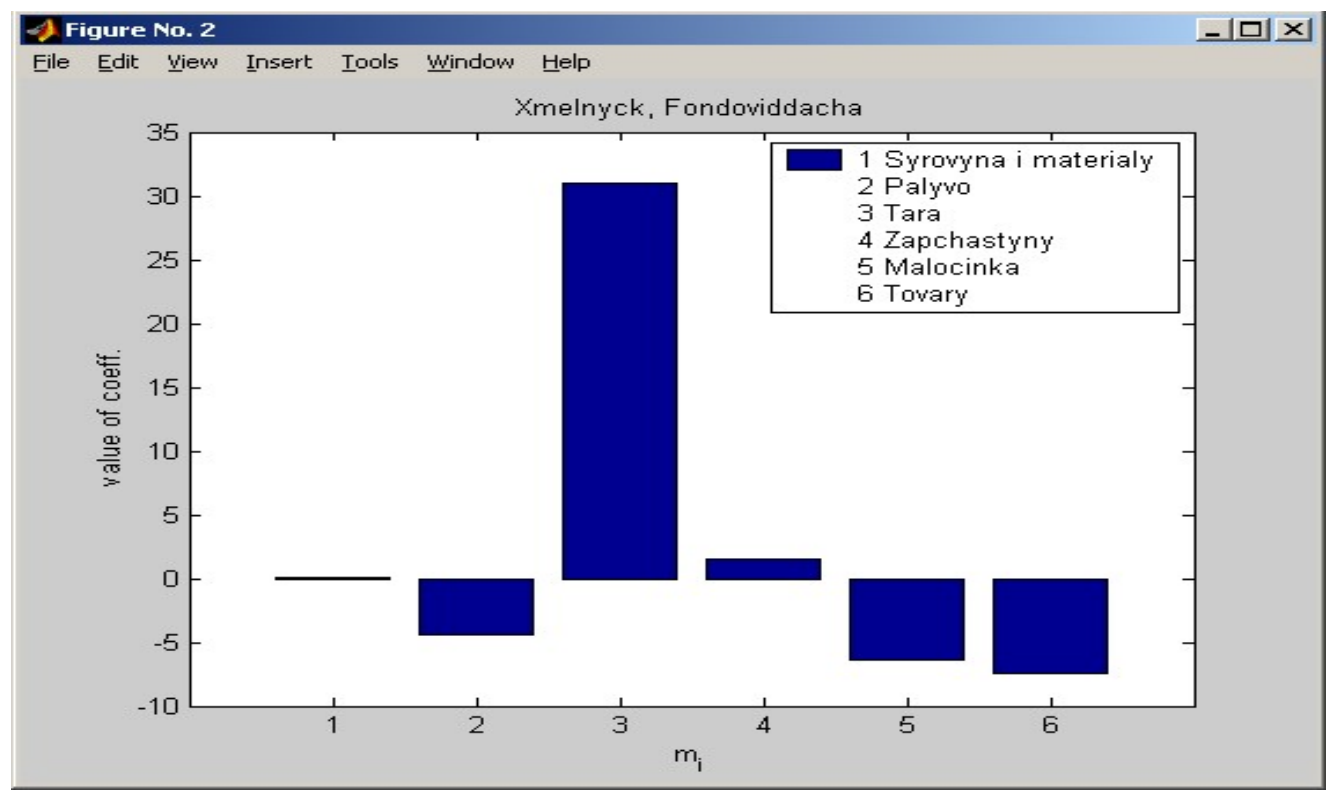

Fig. 3. Diagram of values of coefficients of the non-rationed linear model of dependence of the return on fixed assets on the structure of material supply 
Analyzing the results of the two above-given calculations, we conclude that the return on assets depends primarily on the supply of raw materials, other materials, fuel and construction products.

Fig. 4 shows one of the typical graphs of dependence of the return on fixed assets on the value of resources. It can be seen, that in the case of low cost of some kind of material supply, changes in the volume of this supply have little effect on the return of fixed assets, the excessive supply of more expensive materials causes a slightly accelerated decrease of the return of fixed assets.

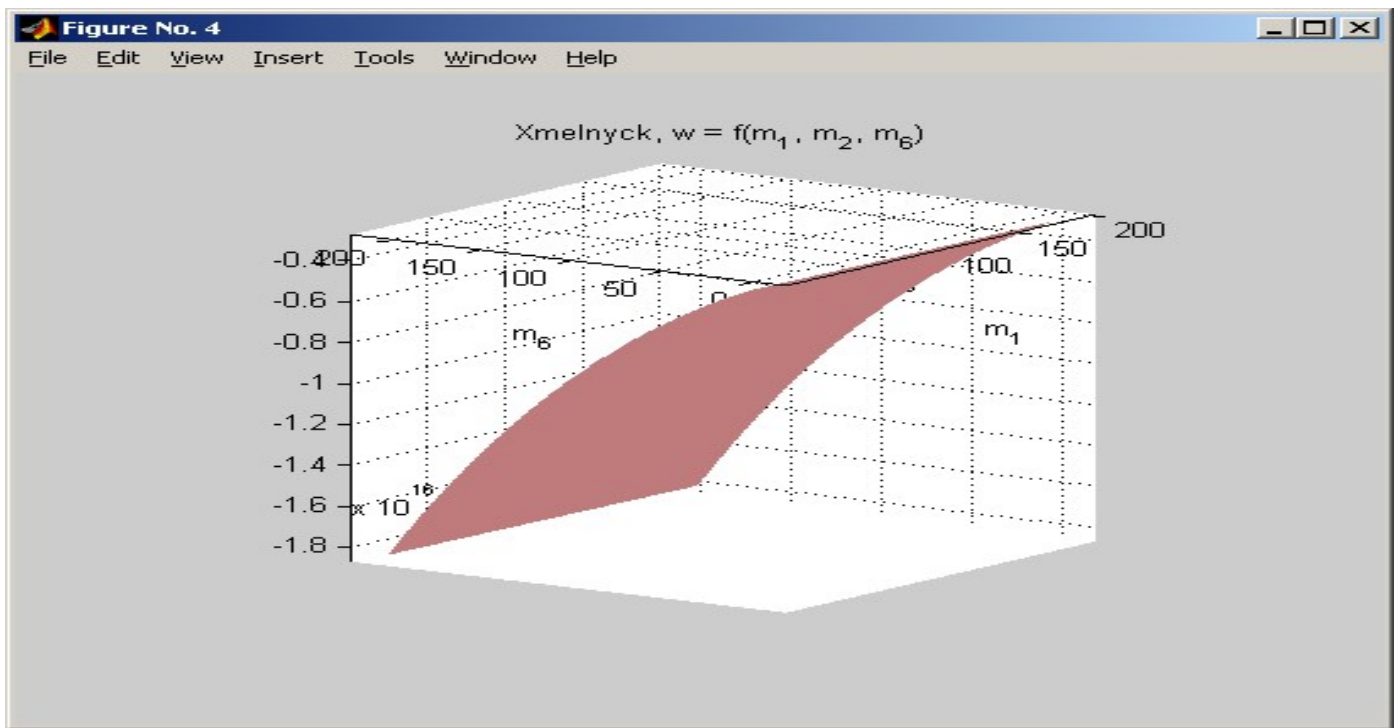

Fig. 4. Typical type of graph of return on fixed assets dependence of CE "Special construction equipment" on the structure of supply of material resources

In the next experiment, the task was to establish a connection between the productivity of the enterprise, the cost of the basic building materials and raw materials and their price. The reason for conducting this experiment was the conclusion from one of the previous models that the return on fixed assets is significantly affected only by a limited stock of raw materials.

Graphs of dependence of cost and price of materials are shown in Fig. 5.

For the analysis, 14 values were taken - the cost and the accounting price of foundations (1), tunnel pipes (2), concrete (3), mortar (4), bituminous concrete (5), bricks (6), crushed stone (7), sand (8), bitumen (9), paint (10), cables (11), gasoline (12), diesel fuel (13), electricity (14).

The analysis of the values of time cost and price of materials of the CE "Special construction equipment" reveals significant shortcomings in the organization of material supply and stock management. As it can be seen from the above-given illustrations (see Fig. 6), stocks often are reduced below the critical limit and are replenished at the time of temporary increase in prices for them. It indicates that organization of material supply is in fact organized considerably worse than it results from the analysis of the production functions that connect profitability with the material supply structure. Therefore, it is advisable to introduce an automated stock management system at CE "Special construction equipment", taking into account the optimal stock size, lot size, insurance reserve, etc.

The diagrams of the values of the found coefficients are shown in Fig. 5. The contents of the coefficients, corresponding to the column numbers in the diagram, are described above.

The results of the calculations, illustrated in the diagrams (Fig. 6), show that most of the materials in the list above do not affect the financial performance of CE "Special construction equipment". Only a few - from three to five - components of materials and resources affect noticeably the financial results of the enterprise under study. 


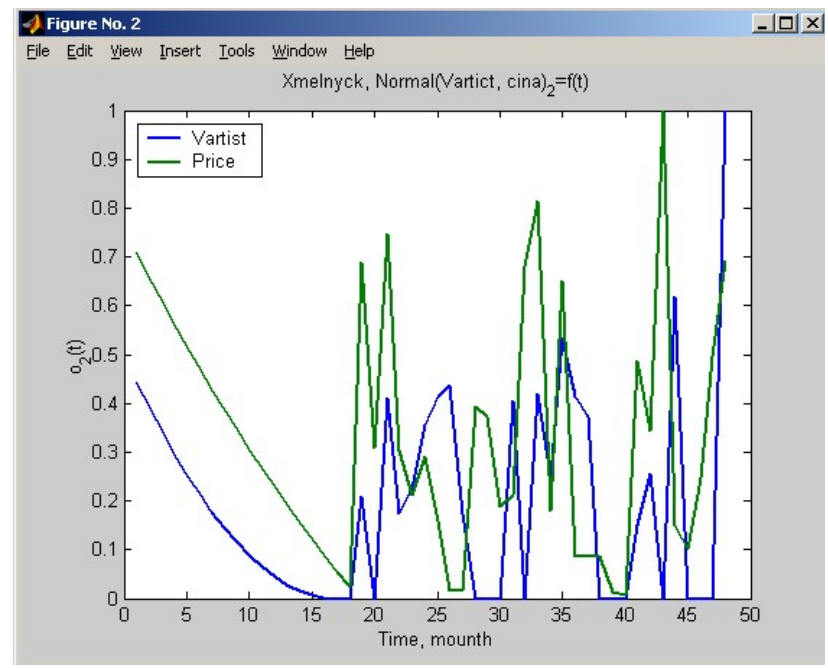

$a$

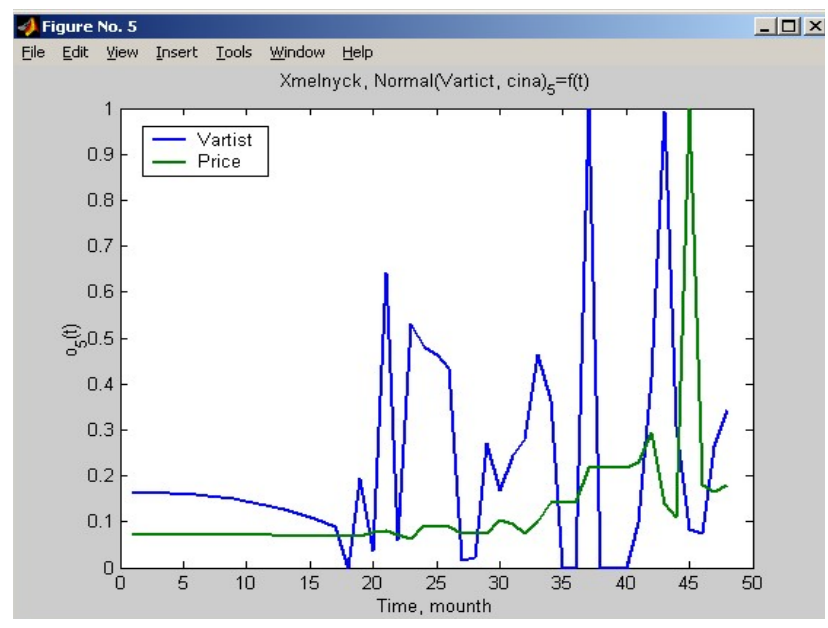

$c$

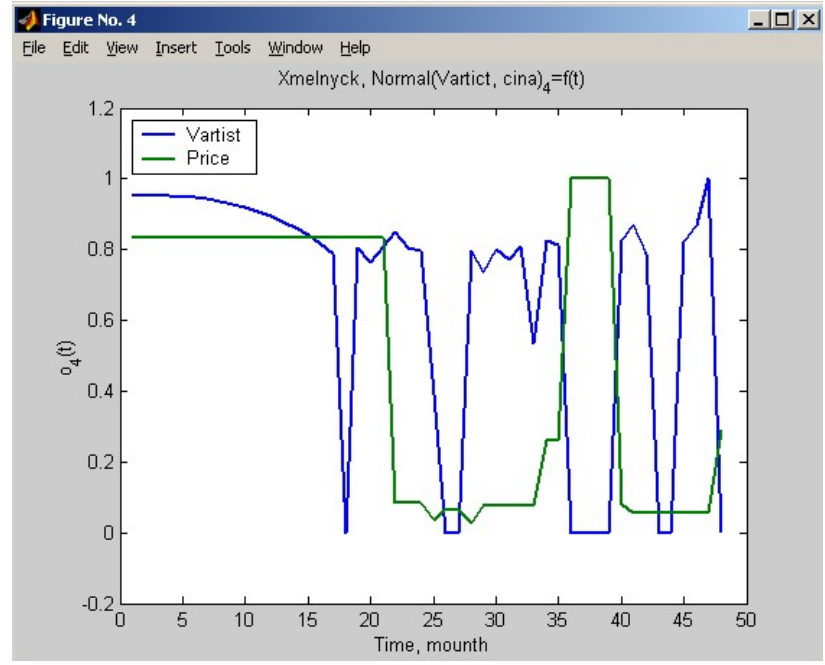

$b$

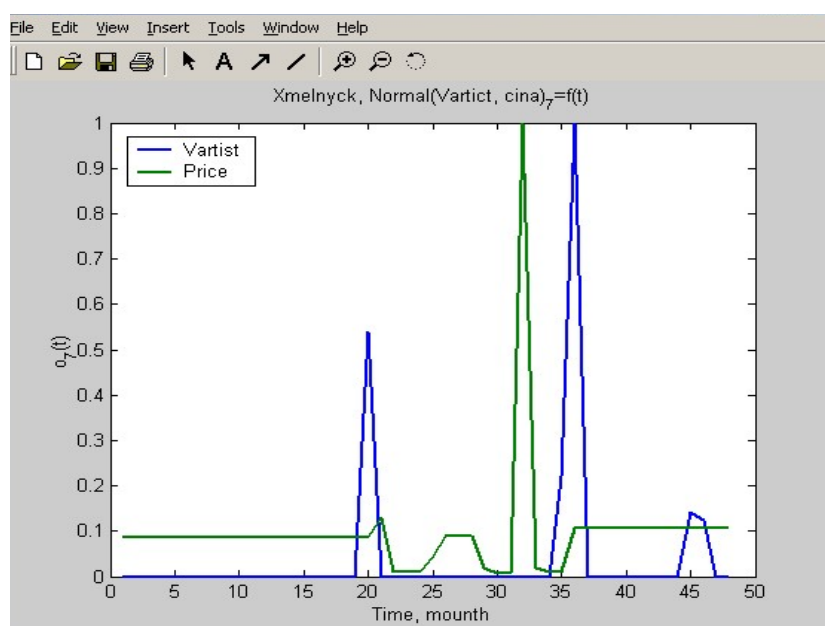

$d$

Fig. 5. Graphs of dependence on the time cost and price of materials: $a$ - tunnel pipes, $b$ - mortar, $c$ - bituminous concrete, $d$ - crushed stone.

As it can be seen from the diagrams in Fig. 6, over the studied period the income, balance and proper capital of CE "Special construction equipment" significantly depended on the cost of products for tunnels, mortar and crushed stone, that proved a large amount of foundation work, with income decreasing depending on the cost of bricks, which indicated a relatively lower profitability of masonry. Gross profit depended on the cost of brick, mortar, tunnel products, crushed stone, and decreased in direct proportion to the cost of the foundation blocks. That is, the gross profit depended on the volume of the erected walls more than the above-mentioned figures. It shows a dual structure of incomes: from foundation and excavations work and from masonry and mounting work. However, the efficiency indicators, modeled on the basis of the linear model equation, point out the importance of these two types of work in different ways.

The profitability of a construction enterprise is influenced by the price of products, purchased for construction. This dependence is revealed by a linear model that relates profitability to the cost of materials and raw materials. As it can be seen from Fig. 7, the income, balance and proper capital of the enterprise over the period studied increased with the rise of the price of foundation blocks and concrete and decreased with the rise of the price of asphalt concrete. This relatively confirms a low profitability of laying asphalt pavement, compared to concrete works. Asphalting may have been a forced unprofitable measure that needed to be applied taking into account 
the complexity of the main types of work. Instead, the price of bituminous concrete had a positive effect on the gross profit of the enterprise, while the impact of the price of other materials differs little from the similar impact on the profit.

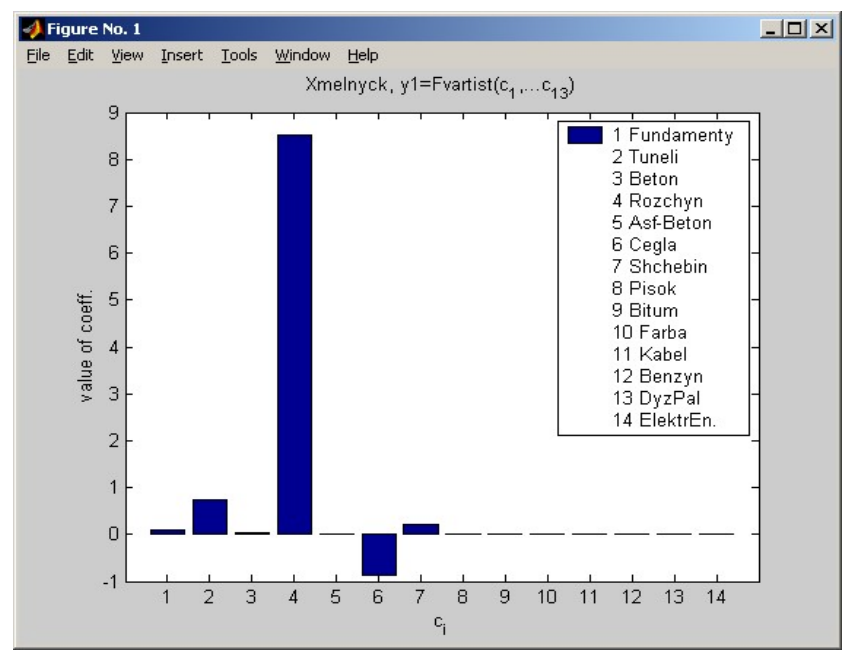

$a$

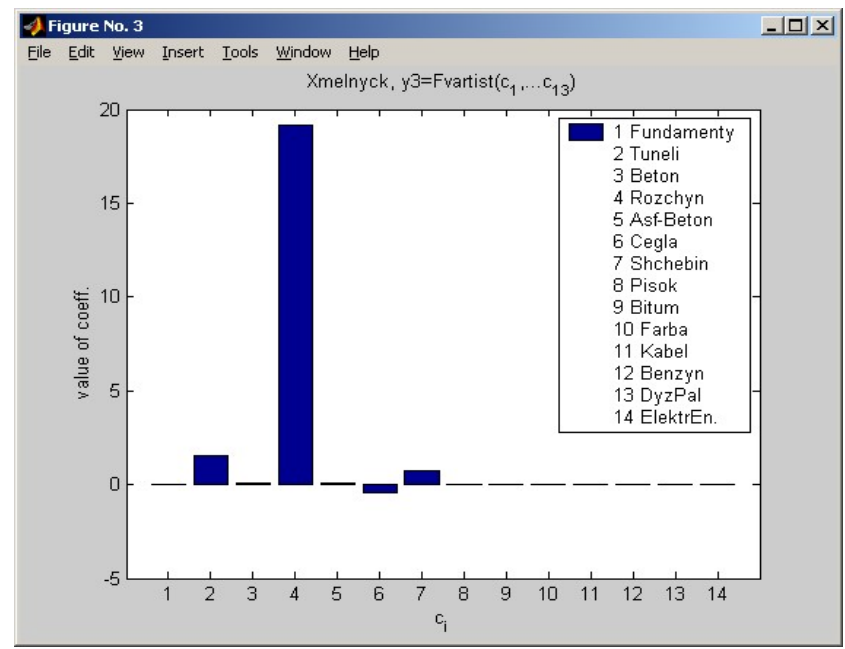

$c$

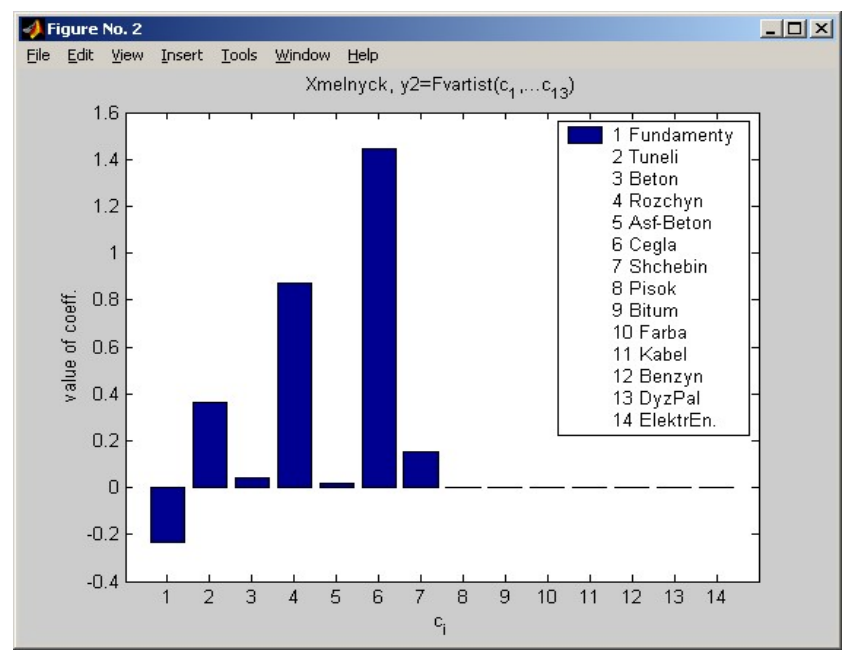

$b$

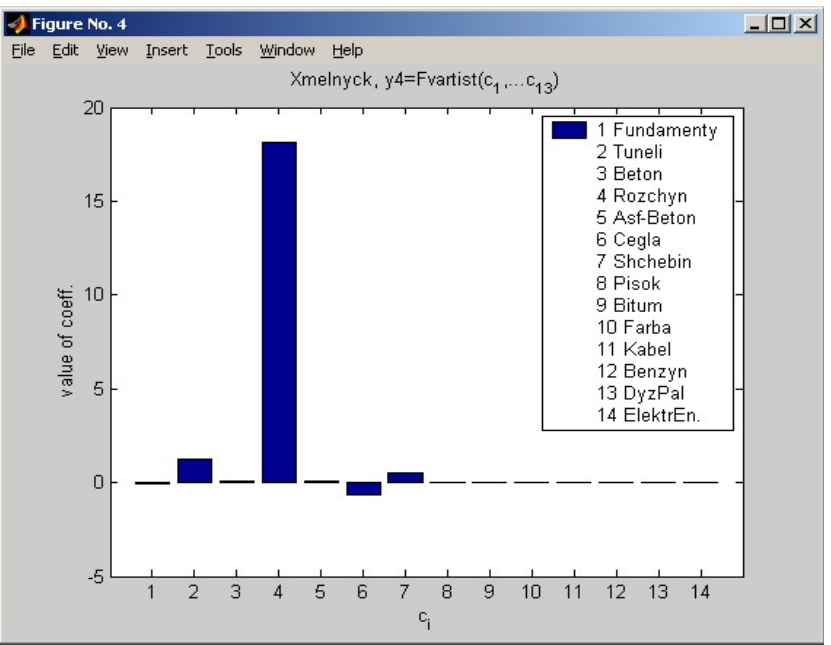

d

Fig. 6. Diagrams of the values of the coefficients of the linear dependencies on the cost of stock: $a$ - net income on sales of products, $b$ - gross profit, $c$ - balance, $d$ - proper capital of CE "Special construction equipment" from the cost of stock

Thus, the analysis of the impact of the cost and price of construction materials shows that the cost of most of them, which are used in small quantities, has little effect on the profitability of the enterprise. Only materials, used in large volumes for two areas of work - foundation concrete and asphalt road, - affect the profitability of the enterprise. Besides that, the dynamics of purchase, production use and sale of finished goods (buildings, living quarters) slightly changes the profitability indicators. It proves the need to improve the income structure. After all, if the profitability indices are differently dependent on the same parameters of cost and price, it indicates the sensitivity of net income from the sale of products to the structure of supply of materials, and therefore, the sensitivity of the enterprise to those types of work and orders which it performs. And it clearly proves that the structure of income of the enterprise is not qualitative. 

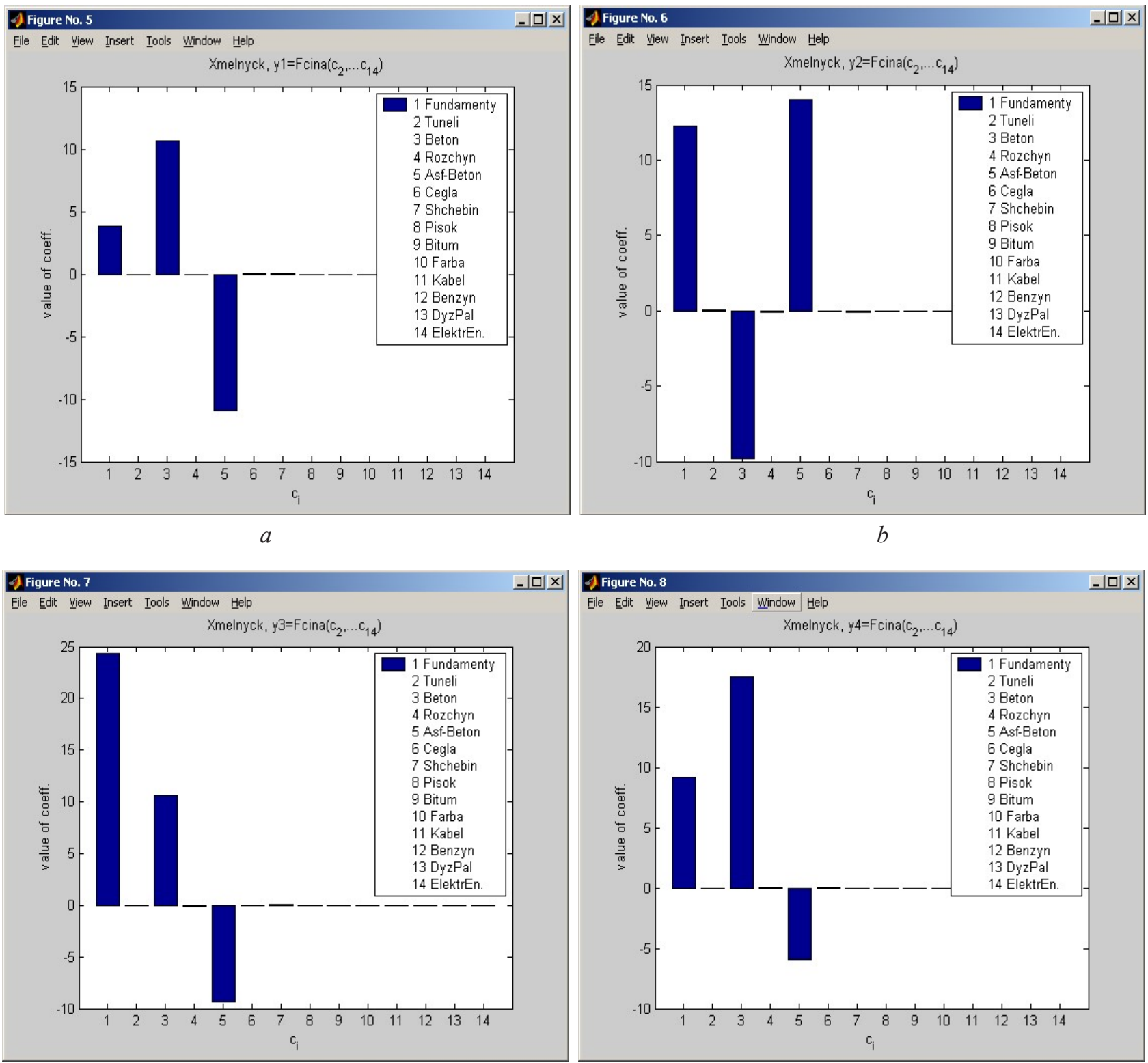

$c$

$d$

Fig. 7. Diagrams of the values of the coefficients of the linear dependencies:

$a$ - net income on sales of products, $b$ - gross profit, $c$ - balance, $d$-proper capital of CE "Special construction equipment" from the price of the unit of measure of stocks.

\section{Conclusions}

The method of research of influence of material supply structure on financial indicators of the activity of contract construction organizations is developed. This method envisages complex combinations of methods of qualitative analysis of the dynamics of material supple, the dynamics of productivity and structural changes in the material supple with modeling the affect of materials recourses supply on the results of return on fixed assets and productivity of labour recourses.

For a preliminary study of the effectiveness of material supply, a comparison of the dynamics of productivity indicators with the dynamics of residual material stocks, their replenishment, withdrawing and replacement is made. All of the above-named values are compared in dynamics with the cost of the stock, its unit price, the lot size of the order, and the order date. 
Based on this qualitative analysis, preliminary conclusions concerning the efficiency of material supply services performance are made, and the relationship between the individual periods of productivity rises and declines and the mode of supply of stock is revealed.

For several dozens of stock items, linear models of connection of productivity indicators with stock residuals, stock arrival, withdrawing, replacement, price, and cost per unit are constructed. On the basis of the analysis of the named linear models, there are pointed out the denominations of stocks, the supply of which does not affect the financial indicators of the organization activity, and the group of stocks that affect the productivity indicators is defined.

Recommendations for managing the balance structure and the supply structure of stocks, which meet the technological needs of the production project, production capacity and labor resources of the organization, as well as the general tendencies to increase its productivity through the intensification of production and its extensive expansion are offered.

The developed method of studying the structure of material stocks is generalized in the methods, which were tested on the data of an individual production organization. The results of application of this method confirm its high practical efficiency.

\section{References}

[1] Homburg, C. (1992). Strategic controlling in practice at Biespiel an engineering company. Der Controlling-Berater, 6, $133-154$.

[2] Karabanyk, S., Mykytiuk, Y. (2018). The role of self-financing in introducing innovative development in construction organizations. Visnyk Ternopilskoho natsionalnoho ekonomichnoho universytetu, 1, 98-105. Available at: http://dspace.tneu.edu.ua/ handle/316497/29178

[3] Mykytyuk, P. P., Kotys, N. V., Mykytyuk, Yu. I. (2020). Methodical approaches to the analysis of the effectiveness of fixed assets of construction organizations on the basis of economic - mathematical modeling. Revista ESPACIOS, 41 (5). Available at: https://www.revistaespacios.com/a20v41n05/20410504.html

[4] Luchko, M. R. (2013). Complex issues in accounting for fixed assets. Socio-Economic Problems and the State, 9 (2), $188-194$. Available at: http://nbuv.gov.ua/UJRN/Sepid_2013_2_21

[5] Lytvyn, B. M., Nikytiuk, M. O. (2004). Orhanizatsiino-ekonomichni metody upravlinnia parkom budivelnoi tekhniky. Ternopil: Ekon. dumka, 120.

[6] Marion, A. (1999). Business Diagnosis. Paris: Ed. Economica, 416.

[7] Mykytyuk, P. P., Soroka, T. M. (2015). Analysis efficiency of the use logistical of buildining organizations. Visnyk Khmelnytskoho natsionalnoho universytetu, 2 (2), 23-26. Available at: http://dspace.tneu.edu.ua/handle/316497/19233

[8] Pylypiv, N. I., Matieshin, M. M. (2014). The methodical aspects of accounting ensuring the process of exploitation basic means of building enterprises. Visnyk Natsionalnoho universytetu "Lvivska politekhnika". Menedzhment ta pidpryiemnytstvo v Ukraini: etapy stanovlennia i problemy rozvytku, 794, 212-220. Available at: http://nbuv.gov.ua/UJRN/ VNULPM_2014_794_31

[9] Sheremet, A. D., Sayfulin, R. S. (2003). Metodika finansovogo analiza. Moscow: INFRA-M.

[10] Krupka, Ya. D., Zadorozhnyi, Z. V., Mykytiuk, N. Ya., Hudz, N. V. (2013). Oblik vytrat pidpryemstva. Finansovyi oblik. Kyiv: Kondor, 385-406.

[11] Mykytiuk, Y. (2019). Management of a portfolio of innovation and investment projects in housing construction. Visnyk Ternopilskoho natsionalnoho ekonomichnoho universytetu, 1, 151-159. Available at: http://dspace.tneu.edu.ua/handle/316497/34045 